\title{
Influence of Pulsed Electromagnetic Seed Treatment on Seed Yield in Soybean (Glycine max L. Merrill)
}

\author{
Bharamaraj Badiger $^{1 *}$ and Ravi Hunje ${ }^{2}$ \\ ${ }^{1}$ Department of Seed Science and Technology, College of Agriculture, \\ Hanumanamatti- 581115, India \\ ${ }^{2}$ University of Agricultural Sciences, Dharwad 580005 Karnataka (India) \\ *Corresponding author
}

A B S T R A C T

\section{Keywords \\ Seed lots, Pulsed electromagnetic field, Seed yield and Seed quality \\ Article Info \\ Accepted: \\ 10 August 2020 \\ Available Online: \\ 10 September 2020}

The field experiments were conducted at Water and Land Management Institute (WALMI), Dharwad while, seed quality parameters were observed at Seed Quality and Research Laboratory, National Seed Project, University of Agricultural Sciences, Dharwad. In the present investigation, Seed lots revealed significant variation on seed yield and quality parameters by treating the seeds with pulsed electromagnetic field treatments on soybean cv. JS-93-05. Fresh seed lot recorded higher seed yield (21.70 $\mathrm{q} / \mathrm{ha}$ ), seed germination $(91.5 \%)$ and seedling vigour index-I (3035) compared to revalidated seed lot Whereas, pulsed electromagnetic field treatment $50 \mathrm{~Hz}(\mathrm{~F} 4)$ recorded significantly higher seed yield $(22.63 \mathrm{q} / \mathrm{ha})$, seed germination $(92.5 \%)$ and seedling vigour index- I (3127) compared to control. There were no significant difference between the interaction of seed lots and pulsed electromagnetic field treatments.

\section{Introduction}

Soybean is one of the world's most versatile and fascinating crop and is recognized as the important oil seed in the world in terms of total production and international trade. In last 30 years, soybean revolutioned and transformed into an export oriented crop. It is the single largest oilseed produced in the world. It alone contributes about 58 per cent of the global oil seed production. Today, it ranks first in oil seed production followed by rapeseed (13\%), groundnut $(8 \%)$ and sunflower $(7 \%)$. Due to its diversified use, the global EXIM trade of soybean has been continuously increased year after year. In spite of this, the national and state productivity are low in comparison with world's average and reasons for this low productivity are large scale cultivation under rainfed and low input conditions.

The major physiological constraints which limit the productivity are lack of seedling vigour, slow development of leaf area during first eight weeks after planting, profuse flowering but poor seed set, limitation of source at the time of seed development due to 
early leaf senescence, inefficient mobilization of carbon and nitrogen as well as malnutrition (Farias, 2004). The past century witnessed a range of chemical application in agriculture to enhance crop production. The negative effects of chemical application on crop production and on the environment are commonly known. Physical methods such as, ionizing, LASER, Ultra-Violet radiation and electric as well as magnetic fields are not only cost effective, but also significantly improve the yield without adversely affecting the environment. Stimulation of plants with magnetic field as a way to increase the quantity and quality of yields has caught interest of many scientists in the entire world.

The uses of specific and highly safe approach of extremely low frequency magnetic fields on crop seeds have shown the marked effects when exposed to pulsed magnetic field (PMF). An alternating current surging forward and backward in a coil winding generates a magnetic field surging back and forth in the coil along its axis and such a magnetic field is referred to as the PMF. Exposure of seeds to this pulsed electromagnetic field before planting is known to change and stimulate a series of biochemical and biological effects in the seeds and plants to achieve the goal of optimizing seed quality (Savostin, 1930). With this background information the studies on response of pulsed electromagnetic field treatment on soybean was carried out.

\section{Materials and Methods}

The plants raised from such pulsed electromagnetic field treated seeds are reported to perform better in the field by exhibiting increased field emergence, early establishment, vigorous growth and increased seed yield and quality. Keeping this in view, the field experiment was laid out in two factorial randomized block design with three replications and a total of ten treatment combinations at the Water and Land Use Management Institute (WALMI) Farm, Dharwad during two consecutive kharif seasons. Fresh and revalidated seeds were exposed to four different frequencies of pulsed electromagnetic field treatment (PMF) viz., $1 \mathrm{~Hz}, 10 \mathrm{~Hz}, 50 \mathrm{~Hz}$ and $100 \mathrm{~Hz}$ and unexposed seeds were considered as control. Other parameter such as the intensity (1500nT), wave form (sine wave) and the duration of exposure ( 5 hours a day for 15 days) were remained same as standardised by the Madras Institute of Magnetobiology (MIM), Chennai (Plate 1 and 2)

\section{Results and Discussion}

In the present findings, seed lots revealed significant variation in various growth parameters at different stages of crop growth irrespective of pulsed electromagnetic field treatments. The pooled data of two kharif seasons revealed that, Significantly higher number of trifoliate leaves at 60 DAS (17.59), less number of days to flower initiation (34.73) and days to 50 per cent flowering (36.50) were observed in fresh seed lot compared to revalidated seed lot (16.65, 35.17 and 36.93, respectively). Seed yield and quality components showed the noticeable differences due to seed lots during the experiment. Fresh seed lot recorded higher number of pods per plant (53.20), number of seeds per plant(3.33), seed yield per plant $(21.63 \mathrm{~g})$, seed yield (21.70 q/ha), 100 seed weight $(12.20 \mathrm{~g})$, seed germination $(91.5 \%)$, seedling vigour index-I (3035), seedling vigour index-II (103.64), seed protein (37.85\%) and seed oil (18.24\%) compared to revalidated seed lot $(51.31,3.23,19.87 \mathrm{~g}$, 20.23 q/ha, 11.94 g, 90.8\%, 2967, 102.39, $37.17 \%$ and $17.62 \%$ respectively) (Table 1 and 2). The significant difference in all the parameters were noticed in fresh seed lot may be due to higher vigour seed which emerged 
better in the field and produced better growth parameters. It is also noted that higher food reserves and higher enzymatic activity exist in fresh seed lot unlike those grown from revalidated seed lot. The higher seed yield of 10.72 per cent was noticed in fresh seed lot over revalidated seed lot may be ascribed to significant increase in number of trifoliate leaves per plant, number of pods per plant, number of seeds per pod,100 seed weight and better plant canopy. These results pointed out the beneficial effect of fresh seed lots in obtaining seeds of superior quality parameters and it might be related to increase in seed yield attributes like number of pods per plant, pod weight per plant and 100 seed weight. Similar results were obtained by Rina and Wahida (2008) in soybean.

In the present investigation, the growth parameters varied significantly due to pulsed electromagnetic field treatments irrespective of seed lots at different growth stages. The number of trifoliate leaves per plant was observed significantly higher in pulsed electromagnetic field treatment $50 \mathrm{~Hz}(18.83)$ compared to control (15.83) at 60 DAS. The days to anthesis and 50 per cent flowering were significantly varied in pulsed electromagnetic field treatment $50 \mathrm{~Hz}$, which took less number of days to anthesis (34.50) and 50 per cent flowering (36.08) compared to control (35.58 and 37.42 respectively). The significant increase in growth parameters noticed under pulsed electromagnetic field treatments in soybean might be due to electromagnetic properties of biological molecule and membrane and bioenergetics structural excitement causing cell pumping and enzymatic stimulation according to Jones et al., (1986) reported that magnetic treated seed affect the regulation of crucial ion mechanism such as ATP hydrogen pump and possibly configuration of pivotal proteins. The total soluble protein map of leaves showed increased intensities of the bands corresponding to large sub unit of $(53 \mathrm{kDa})$ and smaller sub unit $(14 \mathrm{kDa})$ of photosynthetic enzyme rubisco subunits in the treated seed (Shine et al., 2011). Ramalingam and Bollipo (2013) observed that pulsed magnetic field treatment application enhanced the seedling growth by the stimulation of starch degradation, thus might be responsible for improvement of growth parameters and activities of acid phosphatase $(51 \%)$ and alkaline phosphatase $(97 \%)$ were noticed in pulsed magnetic field treatment. It is persuaded that $50 \mathrm{~Hz}$ and $100 \mathrm{~Hz}$ pulsed electromagnetic field treatments showed significant values than other treatment. The present findings are in agreement with earlier findings of Ayub et al., (2012) in Okra.

The marked variations for seed yield components viz., number of pods per plant, number of seeds per pod, seed yield per plant and seed yield per ha were recorded amongst the four pulsed electromagnetic field treatments. The significantly highest number of pods per plant (55.53), number of seeds per pod (3.42), seed yield per plant (23.35 g) and seed yield $(22.63 \mathrm{q} / \mathrm{ha})$ were noticed in the 50 $\mathrm{Hz}$ pulsed electromagnetic field treatment as against control (48.48, 3.13, $17.96 \mathrm{~g}$ and $19.78 \mathrm{q} /$ ha respectively). About 11.44 per cent increase in seed yield per hectare was noticed in $50 \mathrm{~Hz}$ pulsed electromagnetic field treatment over control (Fig 1). This increase in seed yield and its components noticed in pulsed electromagnetic field treatments over control seeds might be due to significant increase in number of branches per plant, number of pods per plant, number of seeds per pod, 100 seed weight and better plant canopy. The beneficial effects of pulsed electromagnetic field treatment has been associated with various biochemical, cellular events and molecular events including enzymatic activity, synthesis of proteins and also increase in ascorbic contents. According to Radhakrishnan and Ranjithakumari (2012) 
pulsed electromagnetic field pre treatment increased protein content with the changes of protein profile in 8 days old seedlings In addition, activity of enzymes such as $\beta$ amylase, acid phosphatase, polyphenol oxidase and catalase was enhanced while $\alpha$ amylase, alkaline phosphatase, protease and nitrate reductase activities declined due to pulsed electromagnetic field exposure. However, a considerable increment of $\mathrm{Fe}, \mathrm{Cu}$,
$\mathrm{Mn}, \mathrm{Zn}, \mathrm{Mg}, \mathrm{K}$ and $\mathrm{Na}$ contents with reduced level of $\mathrm{Ca}$ was found in PMF treated seedlings. The number of leaves, pods, seeds, and 100 seed weight were also remarkably higher in PMF treatment in contrast to control. It suggest that pre treatment of pulsed electromagnetic field plays important roles in improvement of crop productivity of soybean (Fig. 2).

Table.1 Effect of pulsed electromagnetic field treatment on growth and yield attributing parameters in soybean

\begin{tabular}{|c|c|c|c|c|c|c|c|}
\hline Treatments & $\begin{array}{c}\text { Number of } \\
\text { trifoliate leaves } \\
\text { per plant } \\
\text { (60 DAS) }\end{array}$ & $\begin{array}{l}\text { Days to } \\
\text { anthesis }\end{array}$ & $\begin{array}{c}\text { Days to } \\
50 \% \\
\text { flowering }\end{array}$ & $\begin{array}{c}\text { Number } \\
\text { of pods } \\
\text { per } \\
\text { plant }\end{array}$ & $\begin{array}{l}\text { Number } \\
\text { of seeds } \\
\text { per pod }\end{array}$ & $\begin{array}{l}\text { Seed yield } \\
\text { per plant } \\
\text { (g) }\end{array}$ & $\begin{array}{l}\text { Seed yield } \\
\text { per } \\
\text { hectare }(q)\end{array}$ \\
\hline \multicolumn{8}{|l|}{ Seed lots (L): } \\
\hline $\mathbf{L}_{1}:$ Fresh & 17.59 & 34.73 & 36.50 & 53.20 & 3.33 & 21.63 & 21.70 \\
\hline $\mathrm{L}_{2}$ : Revalidated & 16.65 & 35.17 & 36.93 & 51.31 & 3.23 & 19.87 & 20.23 \\
\hline S. Em \pm & 0.19 & 0.08 & 0.07 & 0.48 & $\mathbf{0 . 0 1}$ & 0.24 & 0.23 \\
\hline C.D at $5 \%$ & 0.56 & $\mathbf{0 . 2 3}$ & 0.20 & 1.43 & 0.04 & 0.73 & 0.69 \\
\hline \multicolumn{8}{|c|}{ Pulsed electromagnetic field (F): } \\
\hline $\mathbf{F}_{1}:$ Control & 15.83 & 35.58 & 37.42 & 48.48 & 3.13 & 17.96 & 19.78 \\
\hline $\mathrm{F}_{2}: 1 \mathrm{~Hz}$ & 16.53 & 35.08 & 37.00 & 52.12 & 3.20 & 19.99 & 20.30 \\
\hline $\mathrm{F}_{3}: \mathbf{1 0 H z}$ & 17.18 & 34.83 & 36.67 & 52.75 & 3.28 & 21.01 & 20.86 \\
\hline $\mathrm{F}_{4}: \mathbf{5 0 H z}$ & 18.83 & 34.50 & 36.08 & 55.53 & 3.42 & 23.35 & 22.63 \\
\hline$F_{5}: 100 H z$ & 17.22 & 34.75 & 36.42 & 52.38 & 3.37 & 21.43 & 21.26 \\
\hline S.Em \pm & 0.30 & 0.12 & 0.11 & 0.76 & 0.02 & 0.39 & 0.37 \\
\hline C.D at $5 \%$ & 0.88 & 0.37 & 0.32 & 2.27 & 0.06 & 1.15 & 1.10 \\
\hline \multicolumn{8}{|c|}{ Interactions $(\mathbf{L} \times \mathbf{F})$ : } \\
\hline $\mathbf{L}_{1} \mathbf{F}_{1}$ & 16.33 & 35.33 & 37.00 & 49.67 & 3.17 & 18.87 & 20.07 \\
\hline $\mathbf{L}_{1} \mathbf{F}_{2}$ & 17.13 & 35.00 & 37.00 & 53.37 & 3.23 & 20.90 & 20.68 \\
\hline $\mathbf{L}_{1} \mathbf{F}_{3}$ & 17.50 & 34.50 & 36.50 & 54.70 & 3.37 & 22.59 & 21.53 \\
\hline $\mathbf{L}_{1} \mathbf{F}_{4}$ & 19.40 & 34.17 & 35.83 & 56.33 & 3.47 & 24.23 & 24.25 \\
\hline $\mathbf{L}_{1} \mathbf{F}_{5}$ & 17.57 & 34.67 & 36.17 & 51.93 & 3.40 & 21.56 & 21.95 \\
\hline $\mathbf{L}_{2} \mathbf{F}_{1}$ & 15.33 & 35.83 & 37.83 & 47.30 & 3.08 & 17.05 & 19.48 \\
\hline $\mathbf{L}_{2} \mathbf{F}_{2}$ & 15.93 & 35.17 & 37.00 & 50.87 & 3.17 & 19.08 & 19.91 \\
\hline $\mathbf{L}_{2} \mathbf{F}_{3}$ & 16.87 & 35.17 & 36.83 & 50.80 & 3.20 & 19.44 & 20.18 \\
\hline $\mathbf{L}_{2} \mathbf{F}_{4}$ & 18.27 & 34.83 & 36.33 & 54.73 & 3.37 & 22.47 & 21.01 \\
\hline $\mathbf{L}_{2} \mathbf{F}_{5}$ & 16.87 & 34.83 & 36.67 & 52.83 & 3.33 & 21.30 & 20.57 \\
\hline Mean & 17.12 & 34.95 & 36.72 & 52.25 & 3.28 & 20.75 & 20.96 \\
\hline S.Em \pm & 0.42 & 0.18 & 0.15 & 1.08 & 0.03 & 0.55 & 0.52 \\
\hline C.D at $5 \%$ & NS & NS & NS & NS & NS & NS & NS \\
\hline
\end{tabular}

NS: Non Significant 
Table.2 Effect of pulsed electromagnetic field treatment on seed quality parameters in soybean

\begin{tabular}{|c|c|c|c|c|c|c|}
\hline Treatments & $\begin{array}{l}100 \text { seed } \\
\text { weight } \\
\text { (g) }\end{array}$ & $\begin{array}{l}\text { Seed } \\
\text { germination } \\
(\%)\end{array}$ & $\begin{array}{l}\text { Seedling } \\
\text { vigour } \\
\text { index-I }\end{array}$ & $\begin{array}{l}\text { Seedling } \\
\text { vigour } \\
\text { index-II }\end{array}$ & $\begin{array}{c}\text { Seed } \\
\text { protein } \\
(\%)\end{array}$ & $\begin{array}{c}\text { Seed } \\
\text { oil } \\
(\%)\end{array}$ \\
\hline \multicolumn{7}{|l|}{ Seed lots $(L)$ : } \\
\hline $\mathrm{L}_{1}:$ Fresh & 12.20 & $91.5(73.09)$ & 3035 & 103.64 & 37.85 & 18.24 \\
\hline $\mathrm{L}_{2}:$ Revalidated & 11.94 & $90.8(72.30)$ & 2967 & 102.39 & 37.17 & 17.62 \\
\hline S. $\mathbf{E m} \pm$ & 0.04 & 0.1 & 15 & 0.15 & 0.02 & 0.01 \\
\hline C.D at $5 \%$ & 0.15 & 0.5 & 61 & 0.61 & 0.08 & 0.04 \\
\hline \multicolumn{7}{|c|}{ Pulsed electromagnetic field (F): } \\
\hline$F_{1}:$ Control & 11.84 & $89.9(71.46)$ & 2781 & 101.24 & 37.42 & 17.78 \\
\hline$F_{2}: 1 \mathrm{~Hz}$ & 11.98 & $90.6(72.11)$ & 2995 & 102.39 & 37.45 & 17.92 \\
\hline$F_{3}: 10 H z$ & 12.09 & 91.3(72.87) & 3036 & 103.08 & 37.49 & 17.95 \\
\hline $\mathbf{F}_{4}: \mathbf{5 0 H z}$ & 12.30 & $92.5(74.09)$ & 3127 & 104.91 & 37.65 & 18.04 \\
\hline$F_{5}: 100 H z$ & 12.15 & $91.4(72.94)$ & 3068 & 103.45 & 37.53 & 17.96 \\
\hline S.Em \pm & 0.07 & 0.2 & 24 & 0.24 & 0.03 & 0.02 \\
\hline C.D at $5 \%$ & 0.24 & 1.0 & 97 & 0.97 & 0.12 & 0.07 \\
\hline \multicolumn{7}{|l|}{ Interactions $(\mathbf{L} \times \mathbf{F})$ : } \\
\hline $\mathbf{L}_{1} \mathbf{F}_{1}$ & 12.00 & $90.0(71.54)$ & 2800 & 101.45 & 37.77 & 18.08 \\
\hline $\mathbf{L}_{1} \mathbf{F}_{2}$ & 12.12 & $90.8(72.35)$ & 3011 & 102.93 & 37.79 & 18.22 \\
\hline $\mathbf{L}_{1} \mathbf{F}_{3}$ & 12.27 & $91.8(73.38)$ & 3071 & 103.73 & 37.84 & 18.29 \\
\hline $\mathbf{L}_{1} \mathbf{F}_{4}$ & 12.42 & $92.8(74.63)$ & 3192 & 105.71 & 37.98 & 18.33 \\
\hline $\mathbf{L}_{1} \mathbf{F}_{5}$ & 12.21 & $92.0(73.54)$ & 3102 & 104.40 & 37.85 & 18.27 \\
\hline $\mathbf{L}_{2} \mathbf{F}_{1}$ & 11.69 & $89.8(71.38)$ & 2761 & 101.03 & 37.08 & 17.47 \\
\hline $\mathbf{L}_{2} \mathbf{F}_{2}$ & 11.84 & $90.3(71.86)$ & 2979 & 101.85 & 37.12 & 17.63 \\
\hline $\mathbf{L}_{2} \mathbf{F}_{3}$ & 11.91 & $90.8(72.36)$ & 3002 & 102.44 & 37.14 & 17.62 \\
\hline $\mathbf{L}_{2} \mathbf{F}_{4}$ & 12.19 & $92.1(73.56)$ & 3061 & 104.12 & 37.32 & 17.74 \\
\hline $\mathbf{L}_{2} \mathbf{F}_{5}$ & 12.09 & $90.8(72.35)$ & 3033 & 102.51 & 37.21 & 17.66 \\
\hline Mean & 12.07 & $91.2(72.69)$ & 3001 & 103 & 37.51 & 17.93 \\
\hline S.Em \pm & 0.09 & 0.4 & 34 & 0.34 & 0.04 & 0.02 \\
\hline C.D at $5 \%$ & NS & NS & NS & NS & NS & NS \\
\hline
\end{tabular}

NS: Non Significant

Figures in the parentheses indicate arc sign transformed values 
Fig.1

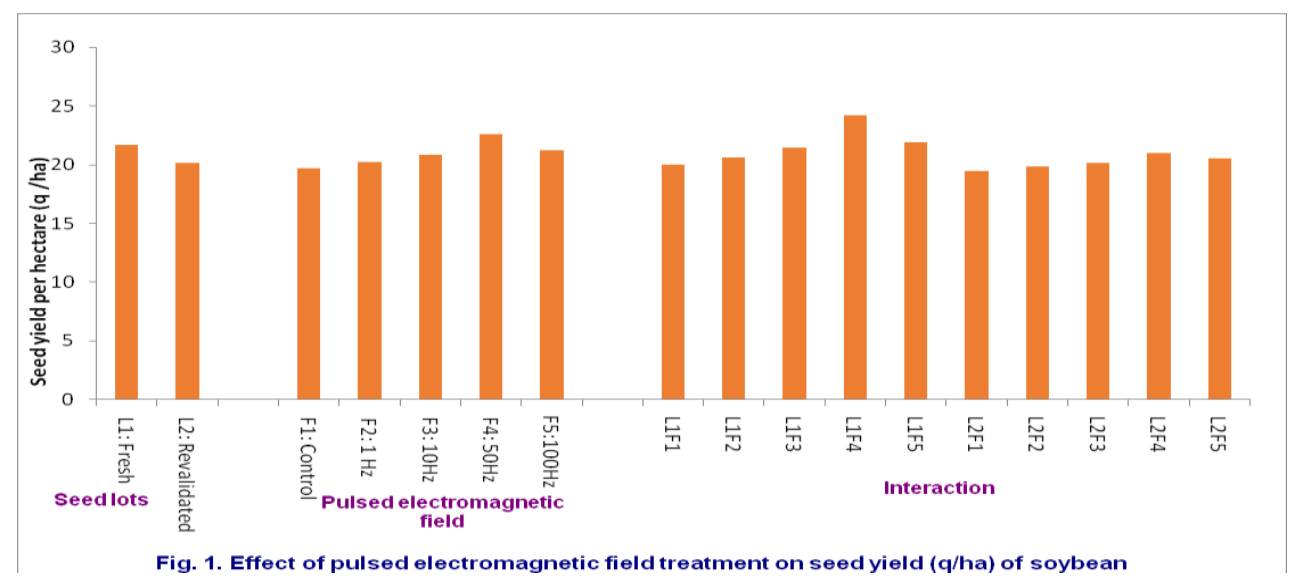

Fig.2

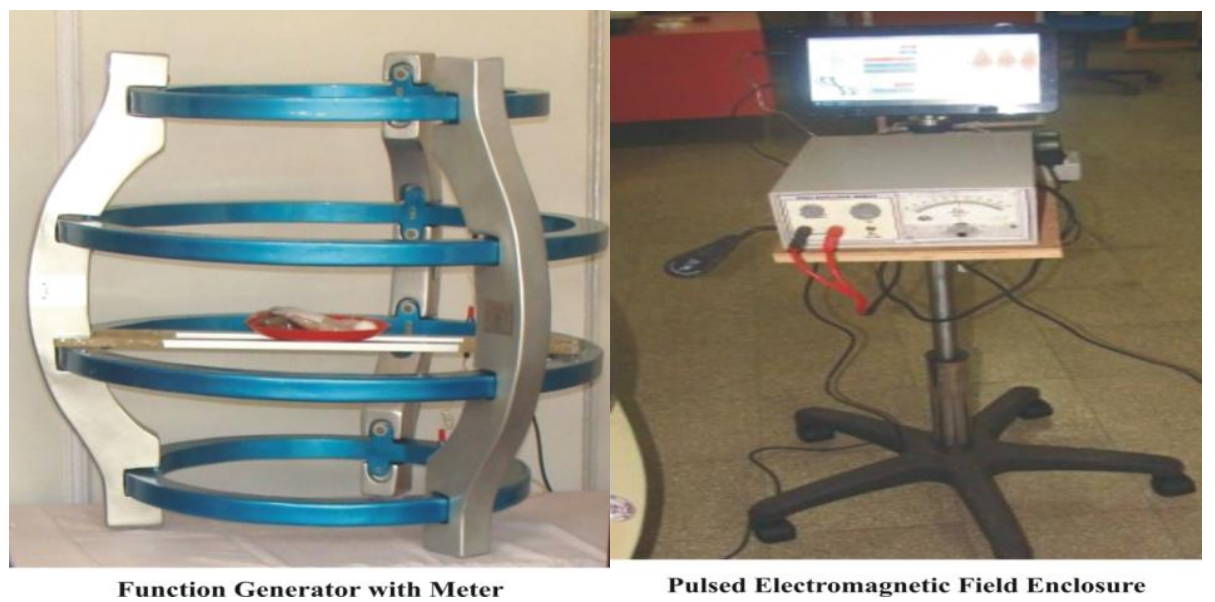

The seed quality parameters showed significant variations due to seed lots irrespective of pulsed electromagnetic field treatment. The fresh seed lot recorded significantly higher 100 seed weight (12.20 g), seed germination (91.5\%), seedling vigour index -I (3035), seedling vigour index -II (103.64), seed protein $(37.85 \%)$ and seed oil (18.24\%) compared to revalidated seed lot (11.94 g, 90.8\%, 2967, 102.39, 37.17\% and $17.62 \%$ respectively). These results pointed out the beneficial effect of fresh seed lots in obtaining seeds of superior quality parameters and it might be related to increase in seed yield attributes like number of pods per plant, pod weight per plant and 100 seed weight.
Similar results were obtained by Rina and Wahida (2008) in soybean

Irrespective of seed lots, the significant variations due to pulsed electromagnetic field treatment was observed for the seed quality parameters. The significantly higher 100 seed weight $(12.30 \mathrm{~g})$, seed germination $(92.5 \%)$, seedling vigour index I (3127), seedling vigour index II (104.91), seed protein $(37.65 \%)$ and seed oil (18.04\%) were recorded in the $50 \mathrm{~Hz}$ pulsed electromagnetic field treatment followed by $100 \mathrm{~Hz}$ as compared to control $(11.84 \mathrm{~g}, 89.9 \%, 2781$, $101.24,37.42 \%$ and $17.78 \%$ respectively). The better seed quality traits noticed in pulsed 
electromagnetic field treatments might be due to an energetic excitement of one or more parameters of the cellular substratum (proteins and carbohydrates) or water inside the dry seeds by the direct effect of magnetic field effect on germination of seed (De Souza et al., 2006). The interaction effect between seed lots and pulsed electromagnetic field treatments ( $\mathrm{L} \times \mathrm{F}$ ) showed non-significant variations for all the growth, seed yield attributing and quality parameters.

From the investigation it could be concluded that, Seed yield and its yield attributing components showed the noticeable differences due to seed lots and pulsed electromagnetic field treatments. Among the seed lot fresh seed lot and exposing the seed to $50 \mathrm{~Hz}$ pulsed electromagnetic seed treatment had profound effect on enhancing the seed yield and quality parameters in soybean.

\section{References}

Ayub, C. M., Pervez, M. A., Zia-ul-haq., Ali, Q., Afzal, M., Khan, N. H., Manan, A. and Hussan, S., 2012, Magnetic field treatment effects on growth of okra (Abelmoschus esculentus (L.) Moench). International J. Bio. Pharmacy. Allied Sci., 1(5): 786-791.

De Souza, A., Garcia, D., Sueiro, L., Gilbert, F., Licea, L. and Porras, E., 2006, Presowing magnetic treatment of tomato seeds increase the growth and yield of plants. Bioelectromagnetic
Biol. and Med., 27: 173-184.

Farias, J. R. B., 2004, Environmental limitations to maximum soybean yield. In: Proc. VII World Soybean Res. Conf., Foz do Iguassu (Brazil), p. 335

Jones, D. B., Bolwell, G.P. and Gilliat, G.J., 1986, Amplification by pulsed electromagnetic fields of plants growth regulator phenylalanine ammonialyase during differential in suspension cultured plant cells. Bioelectricity. 5(1):1-12

Radhakrishnan, R. and Ranjithakumari, B, D., 2012, Pulsed magnetic field: a contemporary approach offers to enhance plant growth and yield of soybean. Plant Physiol Biochem., 51: 139- 144.

Ramalingam, R. and Bollipo, D. R. K., 2013, Influence of pulsed magnetic field on soybean (Glycine max $\quad$ L.) seed germination, seedling growth and soil microbial population. Indian $J$. Biochem. Biophysics., 50: 312-317.

Rina, R. S. and Wahida, S., 2008, Influence of seed ageing on growth and yield of soybean. Bangladesh J. Bot., 37(1): 2126.

Savostin, P. W., 1930, Magnetic growth relations in plants. Planta., 12: 327.

Shine, M. B., Guruprasad, K. N. and Anjali A., 2011, Enhancement of germination, growth, and photosynthesis in soybean by pre-treatment of Seeds with magnetic field. Bioelectromagn., 32: 474-484.

\section{How to cite this article:}

Bharamaraj Badiger and Ravi Hunje. 2020. Influence of Pulsed Electromagnetic Seed Treatment on Seed Yield in Soybean (Glycine max L. Merrill). Int.J.Curr.Microbiol.App.Sci. 9(09): 966-972. doi: https://doi.org/10.20546/ijcmas.2020.909.119 